\title{
Quantitative Dynamics of Chosen Bacteria Phylla in Wastewater Treatment Plants Excess Sludge After Ozone Treatment
}

\author{
Łukasz Jurczyk ${ }^{1 *}$, Justyna Koc-Jurczyk¹, Maciej Balawejder² \\ 1 Chair of Biological Bases of Agriculture and Environmental Education, Department of Biology and Agriculture, \\ University of Rzeszów, Ćwiklińskiej 1a 35-601 Rzeszów, Poland \\ 2 Chair of Chemistry and Toxicology of Food, Department of Biology and Agriculture, University of Rzeszów, \\ Ćwiklińskiej 1a 35-601 Rzeszów. Poland \\ * Corresponding author's e-mail: ljurczyk@ur.edu.pl
}

\begin{abstract}
Among the waste produced by municipal wastewater treatment plants, the largest technological problem is caused by the excessive sludge, the management of which consumes almost half of the costs of the entire installation. Regardless of the final disposal route, which may be, for example, reclamation of degraded areas, the the sludge derived from a wastewater treatment plant should be firstly subjected to a series of processes aimed at: reducing its volume, improving selected physical properties, recovering energy, rot preventing (stabilization) or eliminating epidemiological threats (hygenizing). These goals could be implemented using commonly known technologies, including: dewatering, liming, thermoconditioning, methanogenesis or composting. One of the alternative solutions is the use of ozonation of raw excess sludge, which, in principle, may lead to the simultaneous resolution of several above-mentioned problems, such as: drainage properties improvement, increase the bioavailability of organic matter for biogas production, as well as the removal of undesirable microorganisms. Confirmation of the hygenizing effects usually requires arduous microbiological methods; therefore, the fast and reliable tools of molecular biology could prove their usefulness in this case. In this study, the possibility of determining the dynamics of selected groups of microorganisms (including changes in total bacteria amount, Proteobacteria, Bacteroidetes, Firmicutes and Actinobacteria) after sewage sludge ozonation, by using the semi-quantitative RealTime polymerase chain reaction (qPCR), wasinvestigated.
\end{abstract}

Keywords: ozone treatment, excessive sludge, RealTime qPCR, sludge microbial community, microbial quantitative dynamics

\section{INTRODUCTION}

The operation of wastewater treatment plants (WWTP) is one of the most important factors that have influenced the improvement of environmental condition in recent decades. In the WWTP installation, most of the suspended and dissolved organic as well as mineral pollutants are removed with the efficiency exceeding $90 \%$. As in any other systems based on biochemical processes, the conservation of mass is an obligatory law - discharging to the receiver an effluent which is free of pollutants requires such technology that can change the form of dissolved chemical remove some of them to the atmosphere in a gaseous state (odour, $\mathrm{CH}_{4}, \mathrm{CO}_{2}, \mathrm{NO}_{x}, \mathrm{NH}_{3}, \mathrm{~N}_{2}$ ), and bind the rest chemically or biologically to remove from the system in this form. The excessive sludge created this way, also called sewage sludge, is the main type of waste (both in terms of weight and volume) generated in WWTP installations, and its average quantity is estimated at about $3 \%$ of the volume of treated wastewater. On the other hand, the costs of processing, disposal and utilization may even account for a half of the total operational costs of the WWTP installation. In Poland, the estimated amount of sludge generated throughout a year could reach about 0.5 million tons of dry matter. 
Sewage sludge may differ in composition and properties, depending on the technology used. As a rule, it is a mixture of sludge from primary settling tank, mainly composed of insoluble organic pollutants derived from the separated suspension (mostly decomposing rapidly), and from secondary settling tank, in which the organic matter comes from the activated sludge and is composed of: a biomass of microorganisms, products of their decomposition, adsorbed on sludge flocs, so-called inert (non-degradable), part of suspension, etc. This fraction is less available for biodegradation, among others due to protective effect of cell walls of microorganisms.

The basic technological problems that can be encountered during the processing of the raw excessive sludge include: reduced susceptibility to water drainage, which is of great economic importance due to the limitations on the possibility of reducing the volume of waste generated, high susceptibility to rotting, the side-effect of which is odor nuisance, and the presence of factors being potential health and environmental threats, mainly heavy metal absorbed on flocs, xenobiotics and pathogens, which may disqualify the preselected way of final utilisation. The methods of sewage sludge processing should include all the above-mentioned problems, taking into account the possible direction of their final management.

The classical, widely used methods of excessive sludge disposal can be divided into: chemical, with liming as the main method used, physical mainly thermal processes such as drying, thermoconditioning, gasification, pyrolysis or incineration are dominant (Nadziakiewicz et al., 2012), and biological, including composting, oxygen stabilization or methanogenesis (Kulikowska 2012). In practice, in order to increase the efficiency of treatment, extensive technological lines cover a number of processes, e.g.: after mechanical dehydration, sludge goes to a separate fermentation chamber, and post-treatmet residues are once again dehydrated, dried or hygienized by liming and used for the reclamation of degraded areas (Imhoff et al. 2000). Anaerobic biological stabilization by methanogenic fermentation is becoming an increasingly widespread method of sludge management. Despite significant investment expenditures, the need to carry out detailed process monitoring, and the energy required to maintain the fermentor heat, the main advantage is the positive energy balance, as well as support from the financial tools of pro-environment policy.
Currently, numerous works are underway to increase the energy efficiency of the methanogenesis process; pretreatement of the substrate before feeding the fermenter is essential, and aims at decomposing the inert high molecular mass compounds and destroy resistant prokaryotic cells that make up a significant part of the sludge. A side effect of the bacterial cells breakdown, may be the increase of sludge water drainage factor, pre-hygenizing may be also important to limit the impact on sensitive anaerobic microbial flora of methanogenic fermenter. The proposed methods for breaking up cellular structures are e.g. thermoconditioning or the use of ultrasounds. The application of reactive oxygen species commonly used in tap water treatment, and recently proposed for removing the pharmacological-source micropollutants in wastewater (Dodd 2012) or stabilization of such complex mixtures as landfill leachates (Kwarciak-Kozłowska 2018), seem to be interesting alternatives also in the conditioning of excessive sludge.

Besides testing the wide group of physicochemical parameters that are important from the technological point of view, it is also useful to perform chosen microbiological tests, informing inter alia, on the effectiveness of hygienization, rate of transformation and, above all proving the biological nature of the process. In this case, the methods of molecular biology show many benefits. Rizzo et al. (2013), in the context of studies on antibiotics-resistant bacteria, lists the advantages and disadvantages of molecular techniques in comparison to cultured-based ones. The tools of genetics are, according to the authors, sensitive and specific, the detection is independent of the physiological state of microorganisms, can be based on the taxonomic affiliation (e.g. Nitrosomonas), but also functional genes (eg. amo $A$ ), the exact quantity, or quantitative ratio of DNA copies in the volume unit (water, wastewater, sludge, sediments or soil) is measured directly, and the analysis is not affected by other organisms present in the environment. The disadvantages include: the inability to distinguish between external and intracellular DNA, the risk of cross-reactions with non-identified taxa, presence of the reaction inhibitors that could pass sample extraction process, as well as the need to have specialized equipment, access to reagents and skilled research workforce.

The cultured-based methods, in turn, easily prove the fact of life and reproduction of a given 
microorganism, are reproducible on a long-term scale and between laboratories, and are based on simple principles and relatively cheap. However, the result is affected by the physiological state of microorganisms, furthermore, a significant proportion of live bacteria is not breedable under laboratory conditions, and breeding some of them is very complicated and especially time consuming, even comparing with laborious cultivation of standarized sanitary indicators. The statements above can be confidently applied for the microbiological analysis of most of the environmental samples.

The aim of the study was to calibrate the method of quantitative measurement of chosen groups of microorganisms using Real Time PCR method to use in the laboratory practise to control the biological treatment of municipal and industrial sewage (including landfill leachate) and monitor the process of sewage sludge treatment. In this particular case, the method was used to assess the influence of ozonation on the quantitative shift of selected bacteria phylla in the excessive sludge.

\section{MATERIALS AND METHODS}

\section{Collection of sewage sludge}

Raw excess sludge was collected according to EN ISO 5667-13: 1997 standard from gravity sludge thickener localized in the municipal wastewater treatment plant (WWTP) in Ropczyce (Podkarpackie province, Poland). The WWTP is supplied by a combined sewage system (PE $\approx 6400)$ and operates based on mechanical stage including coarse screen and grid chamber, followed by biological stage consist of predenitrification, dephosphatation, denitrification and nitrification chambers, while the surplus activated sludge is separated in final clarifier.

\section{Sewage sludge ozonation procedure}

In this research, an experimental counter current flow reactor was utilized (pat. appl. P.416306) in the form of column $(\varphi 0.05 \times 2 \mathrm{~m})$ that has a bed (surface area of $8-10 \mathrm{~m}^{2} / \mathrm{m}^{3}$ ) made of plastic, which is characterized by low hydraulic resistance and oxidation resistance. The reactor was fed from the top through a set of pumps by raw sludge. Ozone, as a mixture with oxygen (TS 30 ozone generator, Ozone Solutions), was delivered in counter flow, i.e. from the bottom of the column, under a pressure which allows to overcome the pressure of the precipitate filling the column. Feeding of the gas was carried out through the nozzle generating gas bubbles with a diameter lesser than $0.5 \mathrm{~cm}$. The excess gas went to a residual ozone destructor equipped with a pressure valve and pipeline allowing the unreacted ozone to be recycled to the bottom of the column. It compensates for the amount of gas entering and leaving the installation, which is constantly replenished. If desired, the columns can be combined into a battery of columns by means of connections. The pressure losses are compensated by the pump. The process of the ozonation, based on previous experiences, was carried out for $60 \mathrm{~min}$., and during treatment the ozone concentration ranges between $90-110 \mathrm{ppm}$, at a gas flow of $10 \mathrm{~L} / \mathrm{min}$.

\section{Physio-chemical analyses}

In order to determine the efficiency of treatment process, the parameters listed in Tab. 1 were measured; raw and treated wastewater sludge were examined as to their respiration activity after 4 days (AT4), and the leachate obtained by gravitational draining were examined for organic carbon forms concentration, expressed as COD, $\mathrm{BOD}_{5}$, TOC and VFA.

\section{DNA isolation and amplification}

The samples of raw and ozonated extended sludge were frozen $\left(-20^{\circ} \mathrm{C}\right)$ in $50 \mathrm{~mL}$ tubes immediately after the treatment, and stored in darkness for further isolation of nucleic acid. In order to isolate the nucleic acids sludge, the samples were quickly defrosted in warm water bath (up to $10 \mathrm{~min} / 37^{\circ} \mathrm{C}$ ), manually homogenized, and then $\approx 20 \mu \mathrm{g}$ samples were weighted (Radwag) to standard Eppendorf $1.5 \mathrm{~mL}$ centrifugal tubes. DNA was isolated with commercial kit (Genomic Mini AX Soil Spin, A\&A Biotechnology, Poland), according to the provided protocol: the sampled were suspended in $100 \mu 1$ of BS buffer and lysed first by incubation at $37^{\circ} \mathrm{C}$ for $15 \mathrm{~min}$. with $10 \mu \mathrm{l}$ addition of lysozyme $(10 \mathrm{mg} / \mathrm{mL})$, then, after adding $400 \mathrm{~mL}$ of lysis buffer (LSA), with $20 \mu \mathrm{L}$ of proteinase $\mathrm{K}(20 \mathrm{mg} / \mathrm{mL})$ at $50^{\circ} \mathrm{C}$ for $10 \mathrm{~min}$. The remaining material was separated by short centrifugation $(8000 \mathrm{rpm} / 10 \mathrm{~s})$, and afterwards the DNA was purified on ion exchange membrane columns, then eluted in $100 \mu \mathrm{L}$ of TE buffer and stored in $-20^{\circ} \mathrm{C}$ for further analysis. 
Table 1. Experimental analyses and their measurement methods

\begin{tabular}{|c|c|}
\hline Analysis & Measurement method and reference \\
\hline $\mathrm{AT}_{4}$ (respiration activity after 4 days) & In sludge. Respirometric measurement (OxiTop® WTW, Germany) ISO 16072:2002 \\
\hline COD (chemical oxygen demand) & In leachate. Colorimetric (VELP), PN-ISO 6060:2006 \\
\hline $\mathrm{BOD}_{5}$ (biological oxygen demand) & In leachate. Respirometric (OxiTop® WTW, Germany), DIN EN 1899-1/EN 1899-2 \\
\hline TOC (total organic carbon) & In leachate. PN-EN 1484:1999 \\
\hline VFA (volatile fatty acids) & In leachate. Hermanowicz et al. 1999 \\
\hline${\mathrm{N}-\mathrm{NH}_{4}}^{+}($ammonium nitrogen $)$ & In leachate. Hermanowicz et al. 1999 \\
\hline $\mathrm{N}-\mathrm{N}_{\mathrm{K}_{\mathrm{i}}}($ Kjeldahl nitrogen $)$ & In leachate. Hermanowicz et al. 1999 \\
\hline
\end{tabular}

A set of six pairs of primers (listed in Table 2) was utilized to amplify fragments of $16 \mathrm{~S}$ rRNA gene; universal and those characterized for such phyla as: Proteobacteria ( $\beta$ and $\gamma$ ), Bacteroidetes, Firmicutes and Actinobacteria, supported by universal bacterial primer. Preliminary optimizations of amplification reaction for each pair of primers were performed in Eppendorf Mastercycler termocycyler, whereas quantification PCRs were performed in Roche LightCycler ${ }^{\circledR 96 . ~ T h e r m a l ~}$ profiles was designed as follows: $5 \mathrm{~min}$. of predenaturation in $95^{\circ} \mathrm{C}$, then $40-45$ cycles containing: $15 \mathrm{~s}$ of denaturation in $95^{\circ} \mathrm{C}, 15 \mathrm{~s}$ of primers annealing in $61.5^{\circ} \mathrm{C}$ or $60^{\circ} \mathrm{C}$ (for Beta979F/ Beta1130R), and 20s of elongation in $72^{\circ} \mathrm{C}$. Reaction mix for each sample consisted of: $10 \mu \mathrm{L}$ Real-Time 2xPCR Master Mix SYBR A (A\&A Biotechnology, Poland), $2 \mu \mathrm{L}$ of each primer (10 mM, Genomed, Poland), $1 \mu \mathrm{L}$ of DNA template and nuclease free water added up to total volume of $20 \mu \mathrm{L}$. In order to validate the reaction, the first products were electrophoresed in EtBr stained 2\% agarose gel (Roth) up to 2 hours (Bio-Rad 3V/cm const., 1xTBE), in presence of 100 bp ladder (A\&A Biotechnology), also malting curves were plotted for each reaction. All samples were at least triplicated and amplified in the presence of reagent control samples.
In order to carry out a semi-quantity analysis, the reaction standards were prepared by dilution the amplification product of the aforementioned genes fragments. Firstly, the DNA sample was isolated from fresh activated sludge collected from nitrification chamber of WWTP $(\approx 200000)$ with the method described above, then each gene fragment was amplified (Eppendorf Mastercycler) and electrophoresed. The bands containing amplicons were extracted from the gel and purified on a silica columns (Gel-out, A\&A Biotechnology, Poland), resuspended in TE buffer, then reamplified and checked again by electrophoresis to confirm quality of reaction. The standards prepared in such way were applied in an amount of $1 \mu \mathrm{L}$ per $10 \mu \mathrm{L}$ of PCR mix in a series of 10 -fold dilutions to set calibration curves.

\section{RESULTS AND DISCUSSION}

The design of the AOP reactor utilized in this experiment has an advantage over semi-batch mode, since the sludge can be treated continuously. Additionally, there is no need to use mechanical parts for mixing of the sludge, since the mass exchange is forced by bed of the column. The efficiency of mass exchange was measured

Table 2. Set of 16S rRNA based PCR primers used to assess influence of ozone treatment on sludge was taken form ${ }^{1}$ Bacchetti De Gregoris et al. 2011 and ${ }^{2}$ Yang et al. 2015

\begin{tabular}{|l|l|l|}
\hline \multicolumn{1}{|c|}{ Starter } & \multicolumn{1}{|c|}{ A group of microorganisms (phyllum) } & \multicolumn{1}{c|}{ Oligonucleotide sequence (5' to 3') } \\
\hline $\begin{array}{l}\text { 926F } \\
1062 \mathrm{R}^{1}\end{array}$ & Universal & $\begin{array}{l}\text { AAA CTC AAA KGAATT GAC GG } \\
\text { CTC ACR RCA CGA GCT GAC }\end{array}$ \\
\hline $\begin{array}{l}\text { Cfb798F }^{1} \\
\text { Cfb967R }^{1}\end{array}$ & Bacteroidetes & $\begin{array}{l}\text { CRAACA GGA TTA GAT ACC CT } \\
\text { GGT AAG GTT CCT CGC GTA T }\end{array}$ \\
\hline $\begin{array}{l}\text { Firm 928F } \\
\text { Firm1040R }\end{array}$ & Firmicutes & $\begin{array}{l}\text { TGAAC TYAAAG GAA TTG ACG } \\
\text { ACC ATG CAC CAC CTG TC }\end{array}$ \\
\hline $\begin{array}{l}\text { Act920F3 } \\
\text { Act1200R }\end{array}$ & Actinobacteria & $\begin{array}{l}\text { TAC GGC CGC AAG GCTA } \\
\text { TCR TCC CCA CCT TCC TCC G }\end{array}$ \\
\hline $\begin{array}{l}\text { Beta979F } \\
\text { Beta1130R }\end{array}$ & Betaproteobacteria & $\begin{array}{l}\text { AAC GCG AAAAC CTT ACC TAC C } \\
\text { TGC CCT TTC GTA GCA ACT AGT G }\end{array}$ \\
\hline $\begin{array}{l}\text { Gamma1080F } \\
\text { Gamma1202R }\end{array}$ & Gammaproteobacteria & $\begin{array}{l}\text { TCG TCA GCT CGT GTY GTG A } \\
\text { CGT AAG GGC CAT GAT G }\end{array}$ \\
\hline
\end{tabular}


by analyzing the ozone concentration in the gas stream passing through the reactor. There was an over $90 \%$ loss of the ozone concentration in the outflow from the reactor. This allows drawing the conclusion that the remaining ozone was consumed during the sludge stabilization process.

The respirometric activity of excessive sludge samples increased slightly after ozonation (Tab.3), which may be the result of biochemical activity supression. However, the results of the physiochemical analyzes showed a significant increase of all indicators; in consequence a slight increase in the $\mathrm{BOD} / \mathrm{COD}$ ratio was noticed, with over twice rise of $\mathrm{C} / \mathrm{N}$ proportion, which resulted in a decrease of N-NH ${ }_{4}^{+} / \mathrm{COD}$ and N-NH${ }_{4}^{+} / \mathrm{BOD}_{5}$. The increase in VFA in the pool of organic carbon may have a positive effect on methanogenesis, but there is still a risk of necessity of supplementing the reactor with buffering substances and small amounts of nitrogen.

The laboratory work on the optimization of the quantitative PCR reaction for the activated sludge samples, and set of the reagents and devices used, led to obtaining the highest values of the calibration curves of coefficient of determination (Figure 1); for at least 3 replicates at 5 points (dilutions), in all primer pairs used, R2 was 1 (sic!). The highest value of theoretical efficiency of the PCR reaction of 1.95 and was achieved for the Gamma1080F/1202R primer pair, and in two cases was lower than 1.9 (Actinobacteria and Firmicutes). On the basis of standard curves, the relative changes in the number of DNA fragments representing the selected phylla of microorganisms after the ozonation process were calculated, while the total level of bacterial removal from

Table 3. Mean values and ratios of chemical and biochemical parameters essential for the biodegradability.

\begin{tabular}{|c|c|c|}
\hline Parameter [unit] & Raw sludge & Ozone treated \\
\hline $\mathrm{AT}_{4}\left[\mathrm{mgO}_{2} / \mathrm{kg}_{\mathrm{t.s}}\right]^{*}$ & 2273.5 & 2445.62 \\
\hline $\mathrm{COD}\left[\mathrm{mgO}_{2} / \mathrm{L}\right]$ & 956.8 & 2698.6 \\
\hline $\mathrm{BOD}_{5}\left[\mathrm{mgO}_{2} / \mathrm{L}\right]$ & 268 & 833 \\
\hline TOC [mg/L] & 84 & 180 \\
\hline VFA [mg/L] & 171.4 & 428.57 \\
\hline $\mathrm{N}-\mathrm{NH}_{4}{ }^{+}[\mathrm{mg} / \mathrm{L}]$ & 122.5 & 150.5 \\
\hline $\mathrm{N}-\mathrm{N}_{\mathrm{Kj}}[\mathrm{mg} / \mathrm{L}]$ & 136.5 & 210 \\
\hline $\mathrm{BOD} / \mathrm{COD}$ & 0.280 & 0.31 \\
\hline $\mathrm{N}-\mathrm{NH}_{4}+\mathrm{COD}$ & 0.128 & 0.056 \\
\hline $\mathrm{N}-\mathrm{NH}_{4}{ }^{+} / \mathrm{BOD}_{5}$ & 0.457 & 0.181 \\
\hline $\mathrm{C} / \mathrm{N}$ & 7.810612245 & 17.93089701 \\
\hline
\end{tabular}

*Respirometric activity was investigated in a sample of sludge, whilst the rest of parameters concern leachate the sediment was only about $23 \%$, and $14 \%$ for Firmicutes, Bacteroidetes and Gammaproteobacteria were characterized by the highest sensitivity to ozone -48.5 and $49 \%$ of those groups was removed, respectively.

Complex arrangement of the excess sludge is a result of process of activated sludge in WWTP, and is composed of such microorganisms as bacteria and protozoa, functioning in mutual interdependence (Nielsen et al. 2004). From the point of view of further processing, the microorganisms in excessive sludge can be considered as: a useful source of carbon and biogens, pathogens potentially dangerous to human health and life, organisms that can participate in biological treatment (e.g. composting or methanogenesis), but also impede this processing, e.g. by affecting the complex bacterial communities of the anaerobic digester. The set of PCR primers utilized in this work helps to assess the general changes in the number of microorganisms at the level of chosen phyla (Blackwood et al. 2005).

The phylum Bacteroidetes is composed of three classes of Gram-negative, rod-shaped, nonsporeforming, anaerobic or aerobic bacteria, that are widely distributed in the environment, including soil, sediments and water. One of the genus included - Bacteroides, is an abundant organism in the human feces, but some members are also recognized as opportunistic pathogens (Gupta and Lorenzini 2007). Firmicutes are a phylum of mostly Gram-positive bacteria, creating round or rod-like forms, recently often defined, in contrast to the Actinobacteria, as "the low $-\mathrm{G}+\mathrm{C}$ " group. What is important in the meaning of treatment is that this group may produce endospores, which helps them to survive extreme conditions; thus, they are found in various environments, and also include noticeable pathogens (Wolf et al. 2004) The group is divided into anaerobic Clostridia (e.g. Clostridium, Acetobacterium or Selenomonas), and obligate or facultative aerobic Bacilli (e.g. Bacillus, Listeria, Staphylococcus or Lactobacillus). Actinobacteria are also Gram-positive bacteria living in terrestrial or aquatic biota, known as those having great agricultural importance, by contributing to the decomposition of the organic matter and buffering the soil. Some members can also fix nitrogen and exchange it with higher plants in symbiotic realtionships, while others are severe pathogens as Mycobacterium (Servin et al. 2008). The last group that was measured was Proteobacteria - a major phylum of 

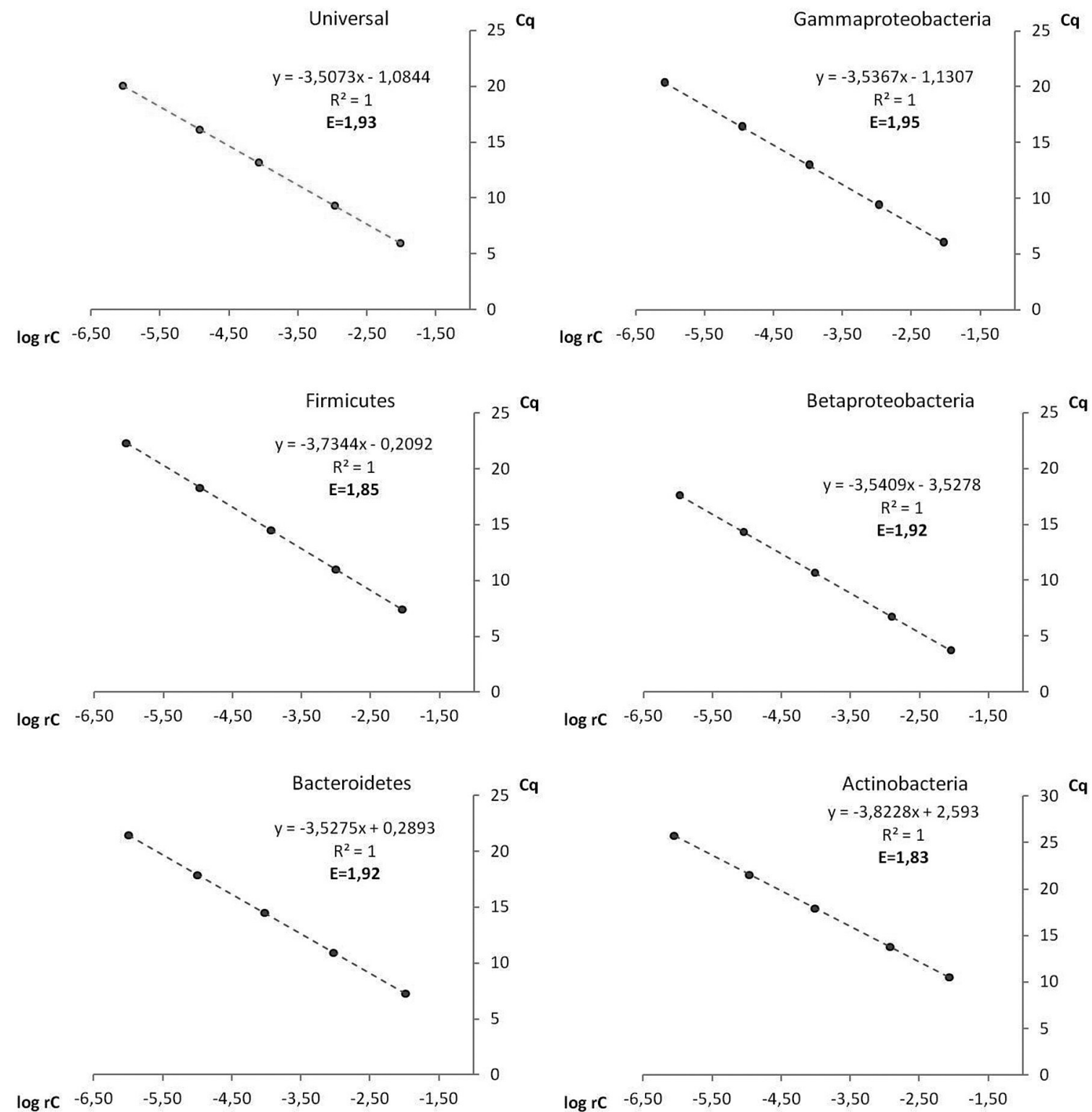

Figure 1. Standard curves based on the relative concentration of target DNA copies corresponding to specific groups of microorganisms. On each graph the slope $(y)$, coefficient of determination $\left(R^{2}\right)$ and calculated theoretical efficiency of polymerase reaction were showed

Gram-negative bacteria, which include a variety of pathogens, such as Salmonella or Vibrio, but also Escherichia, widely used as a model organism or sanitary indicator, and numerous group of free-living bacteria responsible for nitrogen fixation. The last group being in the field of interest is Proteobacteria, a numerous phylum of Gram-negative bacteria, including pathogens, as Salmonella or Vibrio, but also organisms responsible for nitrogen, including those widely utilized in wastewater treatment plant installations. The Betaproteobacteria are highly metabolically diverse, containing chemolithoautotrophs, photoautotrophs, but also heterotrophs, and include such economically important order as Nitrosomonadales (Dworkin et al. 2006). In turn, Gammaproteobacteria are one of the largest class in the meaning of species number, including such important organisms for wastewater treatment installations operation as Beggiatoa genus (causing "bulking") or nitrogen-fixing Azotobacter (Williams et al. 2010).

The mechanism of ozonation against a bacterial cell includes the destruction of cell wall, then leakages of cell content and depolymerization proteins as well as fragmentation of nucleic acids. The efficiency of AOP treatment depends on its time and concentration of radicals, but also vulnerability of each specific bacteria group (Ternes et al. 2015, Funke et al. 2015). 

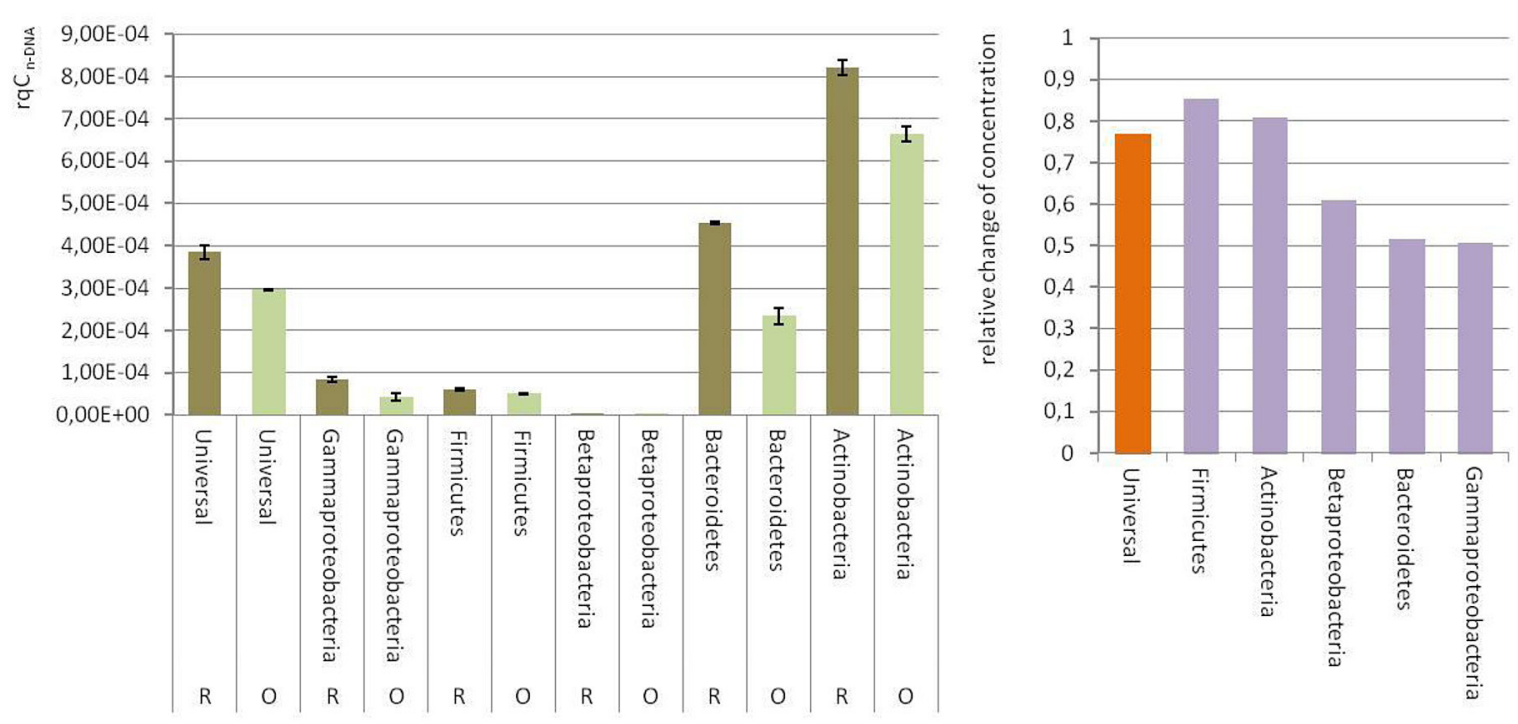

Figure 2. The relative concentrations of target $16 \mathrm{~S}$ rDNA copies in the samples derived from raw $(\mathrm{R})$ and ozone treated $(\mathrm{O})$ WWTP excess sludge are presented on the left side. Note that relative concentration measurement is based on comparing dynamics of a given sample amplification with series of standardized samples with undetermined concentration but known dilutions. The bar chart showing the ratio of gene copies number that represent each groups of bacteria, in relation to its number in the sample before treatment with ozone is presented on the right.

Alexander et al. 2016 studied the effect of ozonation of treated municipal wastewater on the changes in bacterial populations, including the content of antibiotics resistant genes (ARG), by using, among others, quantitative PCR, and qualitative analysis based on DGGE and new generation sequencing. Using the concentration of ozone at the level of $0.9 \mathrm{~g} / 1 \mathrm{~g}$ DOC and HRT $18 \mathrm{~min}$, the authors stated that AOP treatment impact depends on bacteria species, reduces the bacterial diversity, and causes strong population shifts, with an increase of Pseudomonas share, but what is the most interesting, selects vancomycin and imipenem resistant bacteria (with 4- and 7- fold relative increase, respectively). Generally, AOP process reduces the Enterococci bacteria by 99\%, Stapylococci by 78\%, Pseudomonas aeruginosa by $60 \%$ (all the above-mentioned belongs to Firmicutes) and Enterobacteria by $70 \%$ (Gammaproteobacteria). As the authors suggest, ozone treatment selects bacteria with GC-rich genomes. These results were confirmed by Zheng et al. (2017) who studied ARGs in secondary effluents of municipal wastewater treatment plants treated with ozone, UV and chlorination. They reported that the abundance of this marker decreased as disinfectant dosages of UV and chlorine increased. What is interesting, is that the sterilization ability of ozone was the strongest, but its ability to the ARG removal was not significantly enhanced by increasing the $\mathrm{O}_{3}$ concentration. The authors, based on results of DNAse reaction with posttreated samples, assumed that the UV and ozone disinfection resulted in bacterial apoptosis, which consequently leads to a release of ARGs into the environment. Ferro et al. (2017) also stated according to the achieved results, that the $\mathrm{UV} / \mathrm{H}_{2} \mathrm{O}_{2}$ process may not be effective in controlling the potential for AR transfer. Sousa et al. 2017 stated that ozonation and UV radiation may lead to an increase of antibiotic resistance genes prevalence. In turn, Luddeke et al. (2015) found that ozone treatment led to a $16 \%$ increase of antibiotic resistant E. coli and 5.5\% Staphylococcus, but over $25 \%$ decrease of enterococci resistance. Moreover, the species of Enterococcus associated with environment were less sensitive against ozone than fecal associated ones). Jager et al. (2018) investigated the bacteria in the ozone wastewater treatment plants combining molecular analyses (new generation sequencing, qPCR) with livedead discrimination with propidium monoazide - a photoreactive dye that preferentially binds to dsDNA, and thus can be used to detect viable microorganisms by qPCR. The ozone treatment did not influence the number of $P$. aeruginosa (Gammaproteobacteria), whereas a reduction was observed for E. coli (Gammaproteobacteria) and enterococci (Firmicutes). Moreover, comparing with conventional methods of microbiology they 
stated that cultivation overestimate the impact of ozonation, because of the presence of viable but not culturable bacteria. They also discovered a shift in the bacterial community composition amongst the fourteen of most abundant genera identified in the inflow to ozone instalation, nine were reduced, whereas the abundance of four genera relatively increased (including Oscillatoria spp., Microcoleus spp. and Nitrospira spp.). Pseudomonas spp. was the most numerous genera that outflows from the installation.

The analytical technique applied in this paper leads to consider the origin of the amplified DNA. As noted by the above-mentioned authors, the DNA amplified in the PCR process does not have to be the atributable only inside living bacteria at the moment of sample isolation. Bacterial (Prokaryotic) DNA is usually circular, and forms chromosome bound to the cell membranes, and smaller fragments, physically separated from a chromosomal DNA, known as plasmids. In the environmetal sample, the PCR-targeted 16S rDNA genes can occur inside living bacteria, but also inside the cell walls of bacteria that are already dead; moreover, after the breakdown of cell wall structure, outside the cell. Thus, in the scientific literature, it is defined as an intracellular (iDNA) or an extracellular DNA (eDNA). Although Boere et al. (2011) do not include to eDNA the molecules being inside structurally intact dead microbial cells, Corinaldesi et al. (2008) state that eDNA is not associated with living biomass; thus, all molecules of dead organisms are extracellular, even inside the cells. In turn, Nielsen et al. (2007) define eDNA as molecules present inside, or released from cells in which energy production has permanently ceased, but also secreted from metabolically active cells.

DNA as a molecule is relatively stable, some forms, especially circular, under such conditions as: lack of moisture, enzymatic activity, UV radiation or highest temperatures, can retain the integrity over hundreds of thousands years (Brzuzan et al. 2004), but even in the presence of a significant potential of degradation, occurring in such environments as soil, feces, sewage or activated sludge. Laboratory practice proves the possibility of isolating sufficient amounts of DNA template for PCR analysis. Sturdy cell wall structures and the presence of enzymatic systems that reduce the effect of oxidative stress, are the factors that significantly influence the survival time of a molecule when exposed to reactive oxygen species, while the integrity of "naked" eDNA is particularly threatened when exposed to the presence of reactive oxygen species. A comprehensive study on the degradation of DNA molecules by ozone was presented by Cataldo (2006). pure (less than $5 \%$ of proteins) DNA extracted from S.salar milt was subjected to ozonolysis in water solution and solid state. The authors reported that the structure of DNA collapses completely when the molar ratio DNA/O3 reached 2.3 and all thymine and guanine bases were consumed, while ozonolysis proceeds to 1.1 ratio, until the purine and pyrimidine bases are definitely destroyed. What is remarkable, is that they point at fact that DNA in the solid state is much more reactive in an ozone atmosphere than RNA.

\section{CONCLUSIONS}

A set of PCR primers utilized in this work, proposed for environmental samples analysis, like soil or sediments, can be successfully used for the analysis of quantitaive dynamics of microbial communities of sewage sludge subjected to AOP process, as well as to monitor other artificial ecosystems functioning on the basis of biofilm or activated sludge, e.g. biological reactors treating municipal wastewater or landfill leachate. The use of ozonization significantly improves the technological parameters of the sludge; however, it is not sufficient for its total hygienization - this is consistent with the literature data which reported that even the ozonation of treated wastewater, i.e. an aqueous solution in which bacteria are easily available for ozone, does not remove all the microorganisms. The literature data also confirm the result that the ozonation process acts selectively in relation to different groups of bacteria.

The studies were supported in part by the NCN MINIATURA I 2017/01/X/NZ9/00639 project, in terms of calibration of quantitative PCR for activated sludge analysis.

\section{REFERENCES}

1. Alexander J., Knopp G., Dötsch A., Wieland A., Schwartz T. 2016. Ozone treatment of conditioned wastewater selects antibiotic resistance genes, opportunistic bacteria, and induce strong population shifts. Science of the Total Environment, 559, 103-112. 
2. Bacchetti De Gregoris T., Aldred N., Clare A. S., Grant Burgess G.J. 2011. Improvement of phylumand class-specific primers for real-time PCR quantification of bacterial taxa. Journal of microbiological methods, 86, 3, 351-356.

3. Blackwood C. B., Oaks A., Buyer J. S. 2005. Phylum- and Class-Specific PCR Primers for General Microbial Community Analysis. Applied and Environmental Microbiology, 71, 10, 6193-6198.

4. Boere A.C., Sinninghe Damsté J.S., Rijpstra W.I.C., Volkman J.K., Coolen M.J. 2011. Sourcespecific variability in post-depositional DNA preservation with potential implications for DNA based paleoecological records. Organic Geochemistry, 42, 1216-1225.

5. Brzuzan P., Ciesielski S., Kusznierz J., Jurczyk Ł. 2004. Identification of whitefish remains by mtDNA analysis. Annales Zoologici Fennici, 41, 1, 61-68.

6. Cataldo F. 2006. DNA degradation with ozone. International Journal of Biological Macromolecules, 38, 248-254.

7. Corinaldesi C., Beolchini F., Dell'Anno A. 2008. Damage and degradation rates of extracellular DNA in marine sediments: implications for the preservation of gene sequences. Molecular Ecology, 17, 3939-3951.

8. DIN 1899-1/EN 1899-2. Determination of Biochemical Oxygen Demand After N Days (BODn). Beuth Verlag, Berlin, Germany 1998.

9. Dodd M.C. 2012. Potential impacts of disinfection processes on elimination and deactivation of antibiotic resistance genes duringwater and wastewater treatment. Journal of Environmental Monitoring, 14, 7, 1754-1771.

10. Dworkin M., Falkow S., Rosenberg E., Schleifer K.H., Stackebrandt E. 2006. The Prokaryotes, Volume 5 - Proteobacteria: Alpha and Beta Subclasses Springer, 15-18.

11. Ferro G., Guarino F., Cicatelli A., Rizzo L. 2017. $\beta$-lactams resistance gene quantification in an antibiotic resistant Escherichia coli water suspension treated by advanced oxidation with UV/H2O2. Journal of Hazardous Materials, 323, 426-433

12. Funke J., Prasse C., Lütke-Eversloh C., Ternes T. 2015. Oxypurinol - A novelmarker for wastewater contamination of the aquatic environment. Water Research, 74, 257-265.

13. Gupta R.S., Lorenzini E. 2007. Phylogeny and molecular signatures (conserved proteins and indels) that are specific for the Bacteroidetes and Chlorobi species. BMC Evolutionary Biology. 7, 71, 1-18.

14. Hermanowicz W., Dojlido J., Dożańska W., Koziorowski B., Zerbe J. 1999. Physico-chemical examination of water and wastewater. Arkady.

15. Imhoff K.R, Bode H., Evers P. 2000. The ex- amples of municipal sewage treatment desines. Entwurfsbeispiele für kommunale Kläranlagen. Seidel-Przywecki. Szczecin.

16. ISO 16072:2002 Soil quality: Laboratory methods for determination of microbial soil respiration). Beuth Verlag, Berlin, Germany 1998.

17. Jager T., Alexander J., Kirchen S., Dotsch A., Wieland A., Hiller C., Schwartz T. 2018. Live-dead discrimination analysis, qPCR assessment for opportunistic pathogens, and population analysis at ozone wastewater treatment plants. Environmental Pollution, 232, 571-579.

18. Kulikowska D. 2012. Kompostowanie komunalnych osadów ściekowych jako forma recyclyngu organicznego. PAN. Lublin.

19. Kwarciak-Kozłowska A. 2018. Pretreatment of Stabilized Landfill Leachate Using Ozone. Journal of Ecological Engineering, 19, 5, 186-193.

20. Luddeke F., Heß S., Gallert C., Winter J., Gude H., Loffler H. 2015. Removal of total and antibiotic resistant bacteria in advanced wastewater treatment by ozonation in combination with different filtering techniques. Water Research, 69, 243-251.

21. Nadziakiewicz J., Wacławiak K, Stelcmach S. 2012. Thermal processes of waste utilization. Wydawnictwo Politechniki Śląskiej. Gliwice.

22. Nielsen K.M., Johnsen P.J., Bensasson D., Daffonchio D. 2007. Release and persistence of extracellular DNA in the environment. Environmental Biosafety Research, 6, 37-53.

23. Nielsen P.H., Thomsen T.R., Nielsen J.L. 2004. Bacterial composition of activated sludge - importance for floc and sludge properties. Water Science\&Technology, 49, 10, 51-8.

24. PN-ISO 6060, Water quality: Determination of chemical oxygen demand, 2006.

25. Rizzo L., Manaia C., Merlin C., Schwartz T., Dagot C., Ploy M.C., Michael I., Fatta-Kassinos D. 2013. Urban wastewater treatment plants as hotspots for antibiotic resistant bacteria and genes spread into the environment: A review. Science of the Total Environment, 447, 345-360.

26. Servin J.A., Herbold C.W., Skophammer R.G., Lake J.A. 2008. Evidence excluding the root of the tree of life from the actinobacteria. Molecular Biology and Evolution, 25, 1, 1-4.

27. Sousaa J.M., Macedo G., Pedrosa M., BecerraCastro C., Castro-Silva S., Pereira M.F.R., Silva A.M.T., Nunes O.C., Manaia C.M. 2017. Ozonation and UV254nm radiation for the removal of microorganismsand antibiotic resistance genes from urban wastewater. Journal of Hazardous Materials, 323, 434-441.

28. Ternes T.A., Joss A., Öhlmann J. 2015. Occurrence, fate, removal and assessment of emerging contami- 
nants in water in the water cycle (from wastewater to drinking water. Water Research, 72, 1-2.

29. Williams K.P., Gillespie J.J., Sobral B.W.S., Nordberg E.K., Snyder E.E., Shallom J.M., Dickerman A.W. 2010. Phylogeny of Gammaproteobacteria. Journal of Bacteriology, 192, 9, 2305-2314.

30. Wolf M., Müller T., Dandekar T., Pollack J.D. 2004. Phylogeny of Firmicutes with special reference to Mycoplasma (Mollicutes) as inferred from phosphoglycerate kinase amino acid sequence data. International journal of systematic and evolutionary microbiology, 54, 3, 871-875.
31. Yang Y.W., Chen M.K., Yang B.Y., Huang X.J., Zhang X.R., He L.Q., Zhang J., Hua Z.C. 2015. Use of 16S rRNA Gene-Targeted Group-Specific Primers for Real-Time PCR Analysis of Predominant Bacteria in Mouse Feces. Applied and Environmental Microbiology, 81, 19, 6749-6756.

32. Zheng J., Chao S., Zhou J., Xu L., Qian Y., Chen H. 2017. Effects and mechanisms of ultraviolet, chlorination, and ozone disinfection on antibiotic resistance genes in secondary effluents of municipal wastewater treatment plants. Chemical Engineering Journal, 317, 309-316. 